\title{
Physico-chemical and bacteriological characterisation of surface water in Bamenda (North West Cameroon)
}

\author{
Alice Magha Mufur ${ }^{1}$. Margaret Tita Awah ${ }^{1}$. Gus Djibril Kouankap Nono ${ }^{1}$ - Primus Azinwi Tamfuh ${ }^{2,3}$. \\ Pierre Wotchoko ${ }^{1} \cdot$ Kamgang Kabeyene Véronique Beyala ${ }^{4}$
}

Received: 26 April 2020 / Accepted: 11 October 2021 / Published online: 6 November 2021

(c) The Author(s) 2021

\begin{abstract}
The Mezam River and its tributaries constitute a prominent water source for domestic use and vegetable irrigation in Bamenda Town (North West Cameroon). The river flows through the city and is thus vulnerable to impairment by substances from point and non-point sources. This current research aims to assess the degree of pollution of the Mezam River water to ascertain its suitability for various uses. A total of 24 water samples were collected from six segments of the Mezam River basin in the dry and rainy seasons during the years 2015 and 2016 in view of physico-chemical and bacteriological analyses. In situ measurement of physical parameters was taken in the field. The data were analysed by multivariate statistical techniques (principal component analysis and factor analysis). The results revealed that the river water is slightly acidic $(\mathrm{pH}=5.45-6.47)$ and ion concentration is low $(41.67-237.00 \mu \mathrm{S} / \mathrm{cm})$. The water type is $\mathrm{Ca}-\mathrm{SO}_{4}$ and $\mathrm{Ca}-\mathrm{Mg}-\left(\mathrm{Cl}+\mathrm{NO}_{3}\right)$ in the dry season and $\mathrm{Ca}-\mathrm{Mg}-\mathrm{SO}_{4}$ in the rainy season. High $\mathrm{NO}_{3}{ }^{-}$values $(50 \mathrm{mg} / \mathrm{l})$ are recorded at Nkimefueh. The Mezam River water is heavily polluted with indicator bacteria $(0-500 \mathrm{CFU} / 100 \mathrm{ml})$ whose concentrations steadily increase from the reference point (YB) through sampling points in the city centre, suggesting the influence of human-induced activities. The population is urged to adopt a responsible behaviour towards waste disposal and refrain from disposing waste in water courses in order to safeguard the aquatic environment and also protect the health of the population.
\end{abstract}

Keywords Mezam River water $\cdot$ Physico-chemical $\cdot$ Bacteriological analysis $\cdot$ Pollution $\cdot$ Bamenda Town

\section{Introduction}

Water is crucial for the existence of all life forms, yet the precious liquid is overwhelmingly degraded as the world's population continuously skyrockets (Alabi et al. 2020). Ensuring environmental sustainability and promoting the

Alice Magha Mufur

amufur@yahoo.com

1 Department of Geology, Higher Teacher Training College, University of Bamenda, P.O. Box 39, Bambili, Cameroon

2 Department of Soil Science, Faculty of Agronomy and Agricultural Sciences, University of Dschang, P.O. Box 222, Dschang, Cameroon

3 Department of Mining and Mineral Engineering, National Higher Polytechnic Institute, University of Bamenda, P.O. Box 39, Bambili, Cameroon

4 Department of Earth Sciences, Higher Teacher Training College, University of Ngaoundéré, P. O. Box 652, Bertoua, Cameroon sustainable use of water resources is highlighted in the Millennium Development Goal in specific target 7 (UNEP/ GEMS 2006). In addition, the sustainable management of freshwater ecosystems is primordial as these areas constitute the world's most diversified habitats that furnish varied products and services as stipulated in the Sustainable Development Goal (SDG) 6.6 (UN Water 2018). Social, economic and political development is largely related to the availability and distribution of fresh water contained in riverine systems (Simona 2012; Yıldız 2017; UN Water 2018). Major rivers worldwide serve as sources of water supply, irrigation, industrial and municipal use, waste disposal, navigation, hydroelectric plants, fishing, boating, recreation and aesthetics (Chapman 1998; UNESCO 2003; UN Water 2011; Shrikant et al. 2020). However, some of these water services (such as irrigation, waste disposal and industrial services) often lead to deterioration of water quality and quantity (UNEP/GEMS 2006; Fatema et al. 2014; UN Water 2018). In some parts of the world, many rivers are polluted to the point that they are becoming biologically dead (World Bank 
2012). The Mezam River system in Bamenda (Cameroon) lacks protective mechanisms and has been turned by many residents into refuse dumps which makes it unfit for various activities. In this community, like in most developing countries, most industrial, domestic and agricultural wastes flow untreated into the river and its tributaries, thereby posing a serious health threat as thousands of inhabitants continue to depend on the polluted river water for daily use (Ako et al. 2010; Nyenje 2014; Mary Banke et al. 2020). This necessitates an investigation of the river water quality to assess its suitability for various purposes. The works of Tita et al. (2009) in Foumbot, Tita et al. (2013) in Bamenda, Wirmvem et al. (2013) in the Ndop Plain and Rakotondrabe et al. (2017) in Betaré Oya (East Cameroon) have revealed a high level of surface water degradation in Cameroon. Similar works are quite rare in Bamenda, and available information (Kamgang et al. 2010; Nzenti et al. 2010; Nono et al. 2018) in this area is dedicated mostly to petrography. The present work aims to assess physico-chemical characteristics and bacteriological levels of the Mezam River water as well as to investigate their temporal and seasonal fluctuations. The results obtained will serve as a benchmark for various stakeholders in the sustainable management of surface water resources in Bamenda Town and beyond.

\section{Geographic and geologic setting}

Bamenda Town extends from latitude $5^{\circ} 43^{\prime}$ to $7^{\circ} 10^{\prime}$ north and longitude $9^{\circ} 35^{\prime}$ to $11^{\circ} 12^{\prime}$ east and at an altitudinal range of $1200 \mathrm{~m}$ to $1865 \mathrm{~m}$ above sea level. It is characterised by very steep slopes, with slope angles ranging from $45^{\circ}$ to $60^{\circ}$ (Ndenecho and Eze 2004), with a surface area of about 3125 ha (Acho 1998). The climate is essentially the Cameroonian type equatorial domain characterised by two seasons: a rainy season of about 7 months (April to October) and a dry season of about 5 months (November to March). The mean annual rainfall is $2670 \mathrm{~mm}$, and the average annual temperature is $25^{\circ} \mathrm{C}$. The vegetation is typically grassland savannah and has been greatly modified in many areas by the planting of secondary eucalyptus forest (Kometa 2013). The tributary streams (Yambot, Ayaba, Mougheb, Nkimefueh and Naaka) that culminate to form River Mezam originate from the base of the Bamenda Highlands and the Bamenda Escarpment (Molou and Lambi 2006). These water bodies flow through Bamenda city, draining residential areas and commercial centres and form a dense dendritic system. The town is located along the Cameroon Volcanic Line (Fig. 1) and exhibits two very distinct relief environments: the high lava plateau (upstation) with an altitude of about $1400 \mathrm{~m}$ and the lower plateau (downtown) with an average altitude of $1100 \mathrm{~m}$. The upstation and downtown are separated by an escarpment of about $150 \mathrm{~m}$ whose slope steepness attains $35^{\circ}$. Geologically, Bamenda is underlain by a Precambrian granite-gneiss basement which is overlain by volcanic rocks (basalts, trachyte, dolerite and ignimbrites) and sedimentary silty clays of the Mezam River flood plains (Ndenecho and Eze 2004). The dominant soils are ferralsols associated with lithosols and gleysols. Farming is the main activity carried out, and it is mostly crop-based farming, pure pastoral nomadism, mixed crop livestock, secondary and tertiary activities.

\section{Field and laboratory methods}

Water samples were collected from six sampling points (Fig. 1) in the rainy and dry seasons. Two sets of samples were obtained from each station: one for the physico-chemical analysis and the other for the bacteriological analysis. The sampling bottles were initially rinsed with distilled water and, thereafter, with the water to be sampled. After collection the sampling bottles were tightly capped, labelled and placed in an ice-pack cooler to maintain the temperature below $4{ }^{\circ} \mathrm{C}$. The sampling points and their corresponding codes are shown in Table 1 . The water temperature, $\mathrm{pH}$, electrical conductivity, turbidity and dissolved oxygen were measured in situ.

The chemical analysis of the water samples was conducted in the Research Unit of Soil and Environmental Chemistry of the University of Dschang, Cameroon, while the microbiological characteristics were determined in the Laboratory of Animal Physiology and Microbiology of the same university. Major cations $(\mathrm{Ca}, \mathrm{Mg})$ were dosed by the flame atomic absorption spectrometry, while $\mathrm{K}$ and $\mathrm{Na}$ were analysed by the flame atomic emission spectrometry as specified by Atteia (2005). Chloride ions were determined by titration, bicarbonate ions by spectrophotometry and sulphate ions by photometry using barium iodate. Heavy metals were determined using the atomic absorption spectrometry and X-ray fluorescence. The water samples were equally analysed for indicators of faecal contamination such as Escherichia coli (E. coli), Streptococci, Salmonella and Pseudomonas. E. coli was determined by the Most Probable Number (MPN) method using sterile MacConkey broth as described by Cheesbrough (1991), Salmonella and Streptoccocus were dosed from their respective agars according to Cheesbrough (1991), and Proteus was measured by the triple sugar iron (TSI) technique as described by MacFad$\operatorname{din}(2000)$.

\section{Results}

\section{Physical characteristics}

The mean water temperature ranges from $18.3{ }^{\circ} \mathrm{C}$ at $\mathrm{YB}$ to $23.4{ }^{\circ} \mathrm{C}$ at $\mathrm{LN}$. The lowest temperature values are recorded 


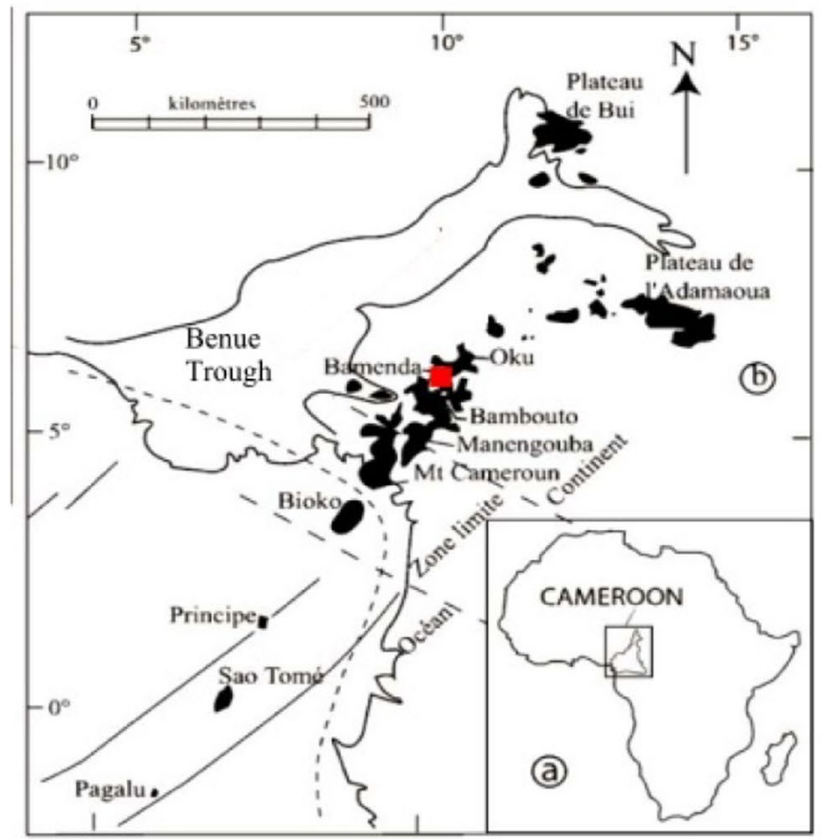

study area

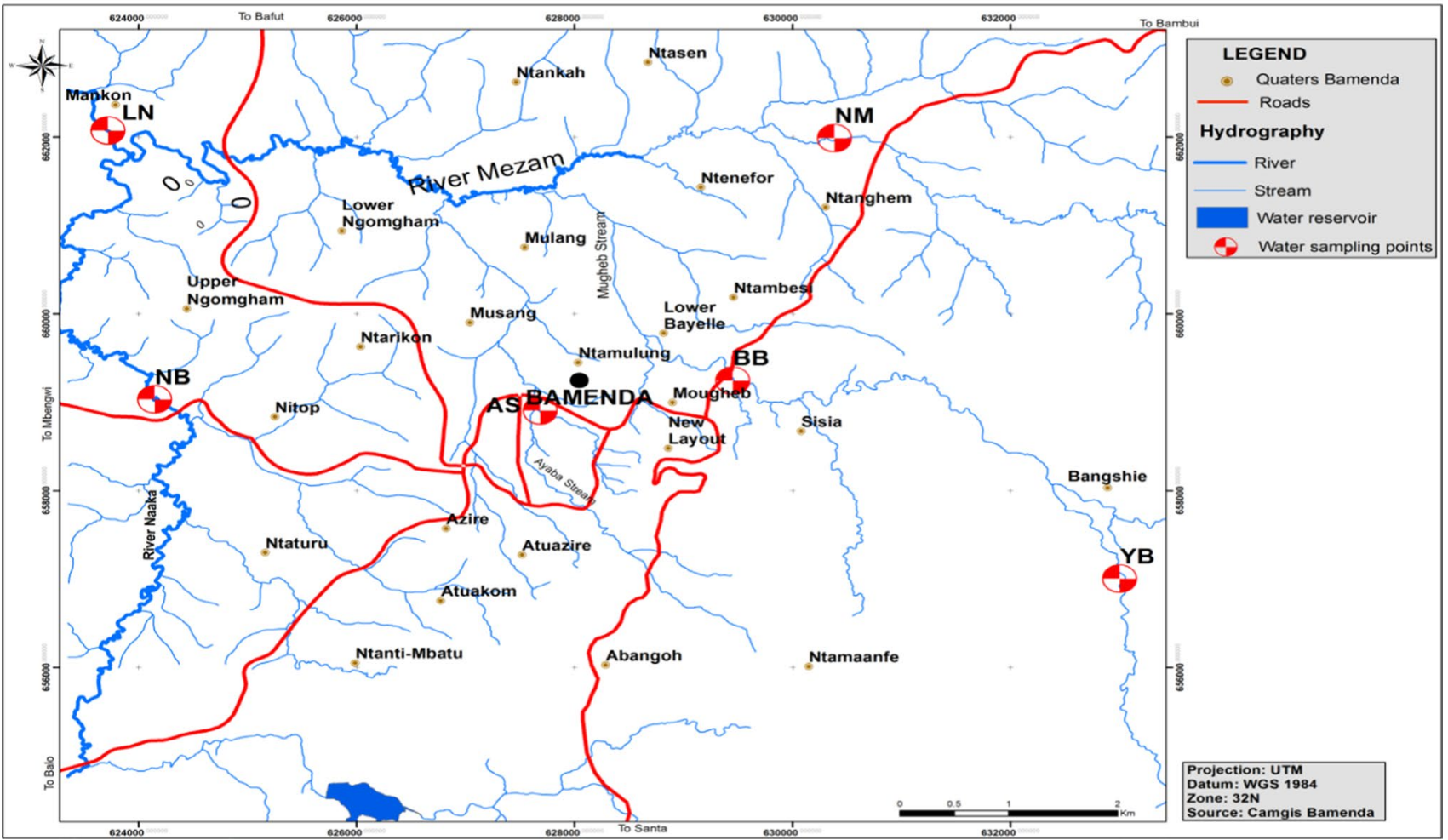

Fig. 1 Geology and location of sampling points in the study area

at $\mathrm{YB}$ and the highest values at $\mathrm{LN}$ (Fig. 2a). The mean $\mathrm{pH}$ values of the Mezam River water range from 5.85 in May to 6.53 in October (Table 2). Seasonal variations are not eminent, with highest values measured in October at NB and lowest at NM during all sampling occasions (Fig. 2b). The mean values of turbidity range from 20.85 NTU in October to $26.93 \mathrm{NTU}$ in the May sampling period. There is a marked seasonal variation at $\mathrm{YB}, \mathrm{BB}, \mathrm{AS}, \mathrm{LN}$ and $\mathrm{NB}$ 
Table 1 Sampling points and their corresponding codes in the study area

\begin{tabular}{|c|c|c|c|c|c|}
\hline Sampling point & Codes & Description of sampling points & Altitude (m) & Latitude & Longitude \\
\hline Yambot (Mendankwe) & YB & Reference point & 1652 & N05 $55^{\prime} 56^{\prime \prime}$ & $\mathrm{E} 10^{\circ} 11^{\prime} 12^{\prime \prime}$ \\
\hline Bayelle segment & BB & $\begin{array}{l}\text { The river receives runoff from habitation, the Nkwen market, } \\
\text { garages and agricultural land }\end{array}$ & 1216 & N055' $58^{\prime \prime}$ & $\mathrm{E} 10^{\circ} 09^{\prime} 49^{\prime \prime}$ \\
\hline Nkimefueh segment (Mile 4) & NM & Receives wastewater from the Bamenda slaughterhouse & 1234 & N05 $59^{\prime} 08^{\prime \prime}$ & $\mathrm{E} 10^{\circ} 10^{\prime} 31^{\prime \prime}$ \\
\hline Ayaba segment & AS & $\begin{array}{l}\text { Receives runoff from the Old Town quarter, the Commercial } \\
\text { Avenue }\end{array}$ & 1237 & N0557'33” & $\mathrm{E} 10^{\circ} 08^{\prime} 51^{\prime \prime}$ \\
\hline Lower Ngomgham & LN & Exit of River Mezam from Bamenda municipality & 1222 & N05 $59^{\prime} 07^{\prime \prime}$ & $\mathrm{E} 10^{\circ} 07^{\prime} 40^{\prime \prime}$ \\
\hline Naaka & NB & $\begin{array}{l}\text { Located in a sparsely populated area where the dominant activ- } \\
\text { ity is agriculture }\end{array}$ & 1221 & N05 $55^{\prime} 22^{\prime \prime}$ & $\mathrm{E} 10^{\circ} 06^{\prime} 55^{\prime \prime}$ \\
\hline
\end{tabular}

Fig. 2 Seasonal variations of physical parameters in the Mezam River water
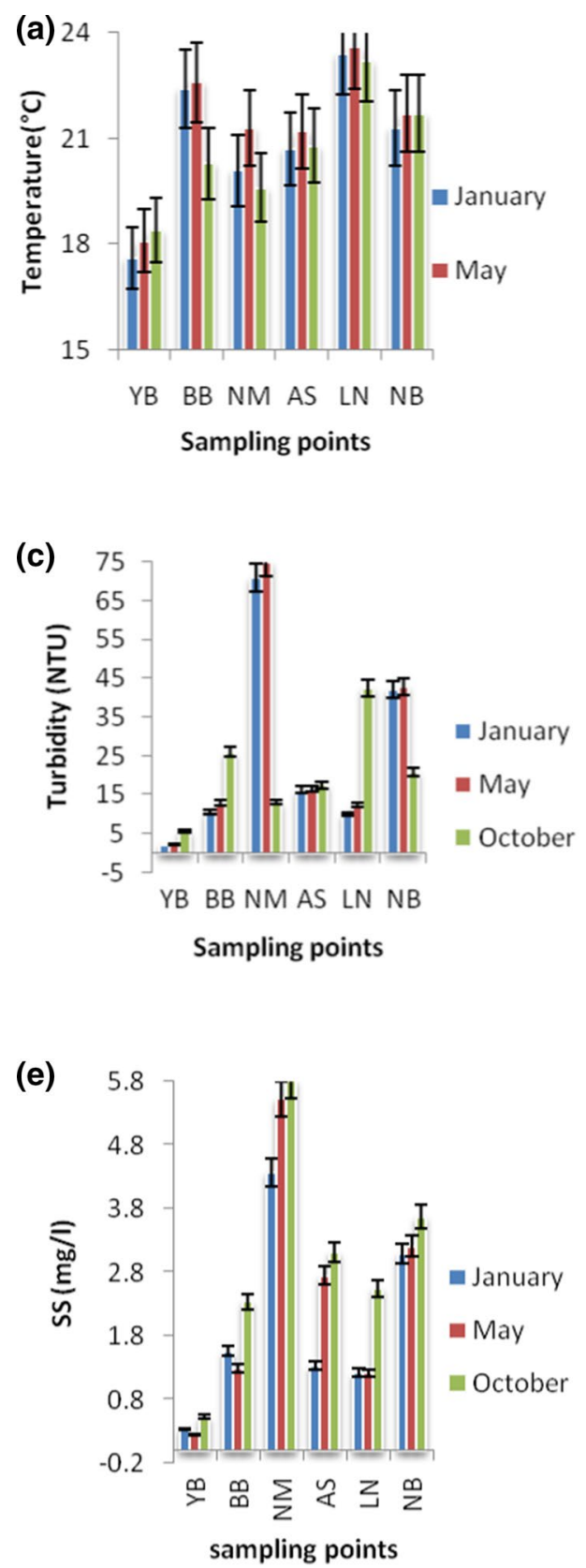

(b)
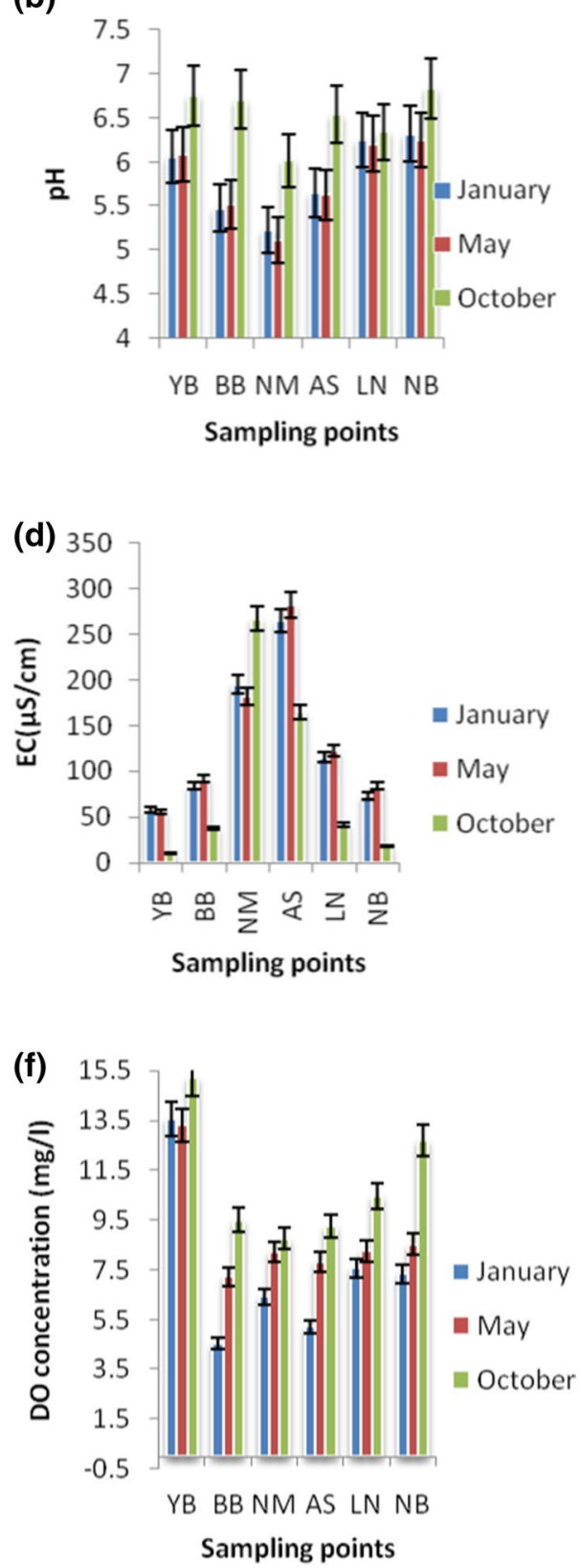
Table 2 Summary statistics of the Mezam water physico-chemical characteristics for the studied period

\begin{tabular}{|c|c|c|c|c|c|}
\hline Variable & Minimum & Maximum & Mean & SD & $\mathrm{CV}(\%)$ \\
\hline \multicolumn{6}{|c|}{ January $(n=6)$} \\
\hline $\mathrm{pH}$ & 5.23 & 6.65 & 6.00 & 0.53 & 8.83 \\
\hline $\mathrm{EC}$ & 73 & 265 & 131.67 & 81.5 & 61.90 \\
\hline Turbidity & 10 & 70.9 & 25.30 & 9.22 & 36.44 \\
\hline $\mathrm{Ca}^{2+}$ & 0.83 & 1.22 & 0.95 & 0.31 & 32.63 \\
\hline $\mathrm{Mg}^{2+}$ & 0.5 & 1.01 & 0.58 & 0.26 & 44.83 \\
\hline $\mathrm{K}^{+}$ & 0.35 & 0.99 & 0.48 & 0.31 & 64.58 \\
\hline $\mathrm{Na}^{+}$ & 0.04 & 0.14 & 0.08 & 0.04 & 50.00 \\
\hline $\mathrm{SO}_{4}{ }^{2-}$ & 0.3 & 0.33 & 0.26 & 0.05 & 19.23 \\
\hline NO3- & 38 & 50 & 42.83 & 6.49 & 15.15 \\
\hline \multicolumn{6}{|c|}{$\operatorname{May}(n=6)$} \\
\hline $\mathrm{pH}$ & 5.12 & 6.21 & 5.80 & 0.45 & 7.76 \\
\hline $\mathrm{EC}$ & 56 & 282 & 136.50 & 83.23 & 60.97 \\
\hline Turbidity & 2.2 & 74.9 & 26.93 & 13.16 & 48.87 \\
\hline $\mathrm{Ca}^{2+}$ & 0.38 & 1.36 & 1.03 & 0.35 & 33.98 \\
\hline $\mathrm{Mg}^{2+}$ & 0.26 & 1.04 & 0.61 & 0.27 & 44.26 \\
\hline $\mathrm{K}^{+}$ & 0.12 & 0.95 & 0.46 & 0.30 & 65.22 \\
\hline $\mathrm{Na}^{+}$ & 0.04 & 0.12 & 0.07 & 0.03 & 42.86 \\
\hline $\mathrm{SO}_{4}{ }^{2-}$ & 0.16 & 0.32 & 0.26 & 0.06 & 23.08 \\
\hline NO3- & 0.04 & 0.12 & 0.07 & 0.03 & 42.86 \\
\hline \multicolumn{6}{|c|}{ October $(n=6)$} \\
\hline $\mathrm{pH}$ & 6.02 & 6.84 & 6.53 & 0.31 & 4.75 \\
\hline EC & 11 & 267 & 90.17 & 33.33 & 36.96 \\
\hline Turbidity & 5.6 & 42.4 & 20.85 & 12.61 & 60.48 \\
\hline $\mathrm{Ca}^{2+}$ & 0.05 & 0.37 & 0.13 & 0.08 & 80.00 \\
\hline $\mathrm{Mg}^{2+}$ & 0 & 0 & 0.06 & 0.03 & 50.00 \\
\hline $\mathrm{K}^{+}$ & 0.02 & 0.07 & 0.07 & 0.03 & 42.86 \\
\hline $\mathrm{Na}^{+}$ & 0 & 0 & 0 & 0.00 & 0.00 \\
\hline $\mathrm{SO}_{4}^{2-}$ & 10.17 & 62.15 & 22.92 & 11.09 & 49.22 \\
\hline NO3- & 6.72 & 16.24 & 9.33 & 3.54 & 37.94 \\
\hline \multicolumn{6}{|c|}{ January + May + October $(n=18)$} \\
\hline $\mathrm{pH}$ & 5.12 & 6.84 & 6.11 & 0.52 & 8.57 \\
\hline EC & 11.00 & 282.00 & 119.44 & 87.12 & 72.90 \\
\hline Turbidity & 2.00 & 74.90 & 24.36 & 21.75 & 89.28 \\
\hline $\mathrm{Ca} 2+$ & 0.05 & 1.36 & 0.70 & 0.49 & 70.00 \\
\hline $\mathrm{Mg}^{2+}$ & 0.00 & 1.04 & 0.42 & 0.33 & 79.62 \\
\hline $\mathrm{K}^{+}$ & 0.01 & 0.99 & 0.33 & 0.31 & 91.56 \\
\hline $\mathrm{Na}^{+}$ & 0.00 & 0.14 & 0.05 & 0.05 & 91.62 \\
\hline $\mathrm{SO}^{2-}$ & 0.16 & 62.15 & 15.87 & 7.80 & 49.16 \\
\hline $\mathrm{NO}^{3-}$ & 0.04 & 50.00 & 19.32 & 17.44 & 90.26 \\
\hline
\end{tabular}

SD: standard deviation; $\mathrm{CV}$ : coefficient of variation

with the lowest values observed in January and the highest values in October (Fig. 2c). The mean values of electrical conductivity (EC) vary in the Mezam River water with mean values ranging from $90.17 \mu \mathrm{S} / \mathrm{cm}$ in October to $136.50 \mu \mathrm{S} /$ $\mathrm{cm}$ in May. With the exception of the NM sampling points, the highest values are scored in January, while the lowest values are noted in October. The lowest $\mathrm{EC}$ value measured during the study period is at YB (Fig. 2d). The concentrations of dissolved oxygen (DO) range from $4.5 \mathrm{mg} / \mathrm{l}$ at $\mathrm{BB}$ to $15.24 \mathrm{mg} / \mathrm{l}$ at $\mathrm{YB}$. The lowest $\mathrm{DO}$ values are measured in January and the highest recorded in October at all the sampling points. There is a high disparity in the DO concentrations from the reference point at YB through the sampling points in the city centre to those downstream as the water exits the city (Fig. 2e). The mean of suspended solids (SS) ranges from $0.37 \mathrm{mg} / \mathrm{l}$ at $\mathrm{YB}$ to $5.24 \mathrm{mg} / \mathrm{l}$ at NM. The highest value of this variable is obtained during the October sampling occasion; meanwhile, seasonal variations are not prominent between the January and May sampling periods. The lowest value of suspended solids is $0.24 \mathrm{mg} / \mathrm{l}$ measured at YB (reference point), while the highest value is $5.82 \mathrm{mg} / \mathrm{l}$ at NM (Fig. 2f).

\section{Chemical characteristics of surface water in Bamenda Town}

The major cations $\left(\mathrm{Ca}^{2+}, \mathrm{Mg}^{2+}, \mathrm{K}^{+}\right.$and $\left.\mathrm{Na}^{+}\right)$in the Mezam River water are in minute concentrations $(0.00$ to $1.36 \mathrm{mg} / \mathrm{l})$ at all the sampling points (Tables 2, 3). The lowest values are observed at YB. All the major cations are present in water samples in the May sampling period (Fig. 3). The highest concentrations of the cations during the study period are observed for $\mathrm{Ca}^{2+}(1.36 \mathrm{mg} / \mathrm{l})$ at NM in May (Fig. 3a), and the least values are obtained during the October sampling occasion. $\mathrm{Mg}^{2+}$, on the other hand, is absent at the NB and YB sampling points (Fig. 3b). Low $\mathrm{Na}^{+}$and $\mathrm{K}^{+}$levels are observed at all the sites.

Major anions $\left(\mathrm{Cl}^{-}, \mathrm{HCO}_{3}{ }^{-}, \mathrm{SO}_{4}{ }^{2-}\right)$ appear in very low concentrations in the Mezam River water (0.00-3.2 mg/l). The chloride ion varies from $0.00 \mathrm{mg} / \mathrm{l}$ to $0.09 \mathrm{mg} / \mathrm{l}$ (Fig. 3a). Seasonal variations are not very perceptible except at BB, $\mathrm{NM}$ and LN (Fig. 4a). The highest mean concentration $(0.09 \mathrm{mg} / \mathrm{l})$ is recorded at NM in May and the lowest at YB. The bicarbonate ion ranges from $0.11 \mathrm{mg} / \mathrm{l}$ to $3.2 \mathrm{mg} / \mathrm{l}$, and seasonal variations are observed with lowest levels recorded in October and about $95 \%$ of the highest concentration is noted in January (Fig. 4b). The lowest level of the bicarbonate ion is $0.86 \mathrm{mg} / \mathrm{l}$ at $\mathrm{YB}$ and the highest is $3.2 \mathrm{mg} / \mathrm{l}$ at NB. The mean concentrations of sulphate ions range from $0.18 \mathrm{mg} / \mathrm{l}$ to $0.31 \mathrm{mg} / \mathrm{l}$ (Fig. $4 \mathrm{c}$ ). Low levels of sulphate ion $(0.01 \mathrm{mg} / \mathrm{l})$ are observed in May and October with no perceptible trend, while higher levels appear in January.

The concentrations of phosphate ions vary from $0.03 \mathrm{mg} / 1$ to $0.12 \mathrm{mg} / \mathrm{l}$, with no significant variation between seasons and among the sampling points. The lowest mean concentration of the phosphate ion is $0.05 \mathrm{mg} / \mathrm{l}$ at $\mathrm{YB}$, and the highest is $0.075 \mathrm{mg} / \mathrm{l}$ at NB (Fig. 5a). The mean concentration of nitrate ions varies from $13.25 \mathrm{mg} / \mathrm{l}$ to $19.77 \mathrm{mg} / \mathrm{l}$ in the Mezam River water. The lowest 
Table 3 Principal component analysis generated based on factor loading $(n=18)$
Fig. 3 Seasonal variations of major cations $(\mathrm{mg} / \mathrm{l})$ in the Mezam River water

\begin{tabular}{llccc}
\hline & $\mathrm{PC} 1\left(\mathrm{pH} / \mathrm{Ca}^{2+} /\right.$ & $\mathrm{PC} 2$ (Proteus) & PC 3 (Salmonella) & PC 4 (EC) \\
& $\left.\mathrm{Mg}^{2+} / \mathrm{K}^{+} / \mathrm{Na}^{+}\right)$ & & & 0.10 \\
$\mathrm{pH}$ & $\mathbf{- 0 . 8 1}$ & 0.40 & 0.07 & $\mathbf{0 . 7 5}$ \\
$\mathrm{EC}$ & 0.47 & -0.37 & 0.15 & -0.03 \\
Turbidity & 0.64 & 0.29 & 0.25 & 0.08 \\
$\mathrm{Ca}^{2+}$ & $\mathbf{0 . 8 9}$ & -0.12 & -0.06 & -0.03 \\
$\mathrm{Mg}^{2+}$ & $\mathbf{0 . 9 8}$ & -0.12 & -0.12 & -0.02 \\
$\mathrm{~K}^{+}$ & $\mathbf{0 . 9 5}$ & -0.14 & -0.19 & -0.06 \\
$\mathrm{Na}^{+}$ & $\mathbf{0 . 9 7}$ & 0.04 & -0.05 & 0.65 \\
$\mathrm{SO}^{2-}$ & -0.47 & -0.23 & 0.00 & 0.35 \\
$\mathrm{NO}^{3-}$ & 0.31 & 0.56 & -0.49 & 0.33 \\
E.coli & 0.11 & 0.61 & 0.46 & -0.12 \\
Streptococcus & 0.51 & 0.47 & 0.50 & -0.05 \\
Salmonella & 0.11 & -0.34 & $\mathbf{0 . 8 0}$ & 0.07 \\
Proteus & 0.13 & $\mathbf{0 . 7 0}$ & -0.08 & 1.26 \\
Total loading & & 1.98 & 1.49 & 9.700 \\
\% variance explained & 5.49 & 15.23 & 11.51 & 78.72 \\
Cumulative \% variance explained & 42.27 & 57.51 & 69.02 & \\
\hline
\end{tabular}

The very high factor loadings of some variables in bold imply that the chemistry of water is controlled mainly by those variables
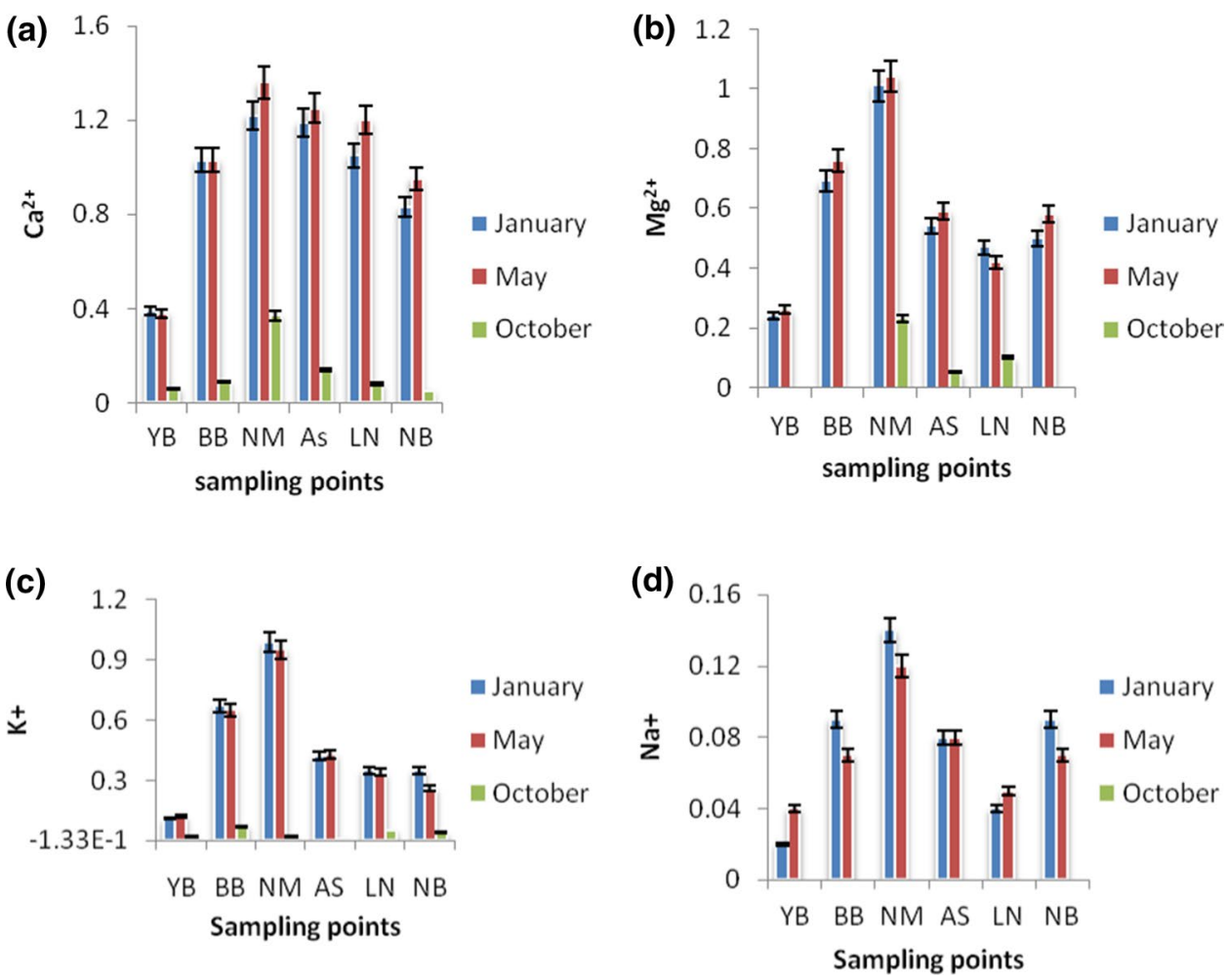

concentration $(0.04 \mathrm{mg} / \mathrm{l})$ is obtained in May at $\mathrm{YB}$ and the highest $(50 \mathrm{mg} / \mathrm{l})$ in January at NM (Fig. 5b). The mean concentration of the ammonium ions ranges from $33.27 \mathrm{mg} / \mathrm{l}$ to $44.79 \mathrm{mg} / \mathrm{l}$. Seasonal variations are noted with the lowest concentration $(7.84 \mathrm{mg} / \mathrm{l})$ measured in October (rainy season) and the highest $(63 \mathrm{mg} / \mathrm{l})$ in May, except at AS (Fig. 5c). The spatial variations are also noted with the highest concentration $(63 \mathrm{mg} / \mathrm{l})$ recorded at $\mathrm{LN}$ in May and the lowest $(7.8 \mathrm{mg} / \mathrm{l})$ at $\mathrm{NM}$ in October.

The Piper's ternary diagram (Piper 1953) enables the identification of three main hydrochemical water types (Fig. 6). In the dry season, two water types are noted, the $\mathrm{Ca}-\mathrm{SO}_{4}{ }^{2-}$ type and the $\mathrm{Ca}-\mathrm{Mg}-\mathrm{Cl}+\mathrm{NO}_{3}{ }^{-}$type. For the cations, some of the samples plot in the calcium domain and 

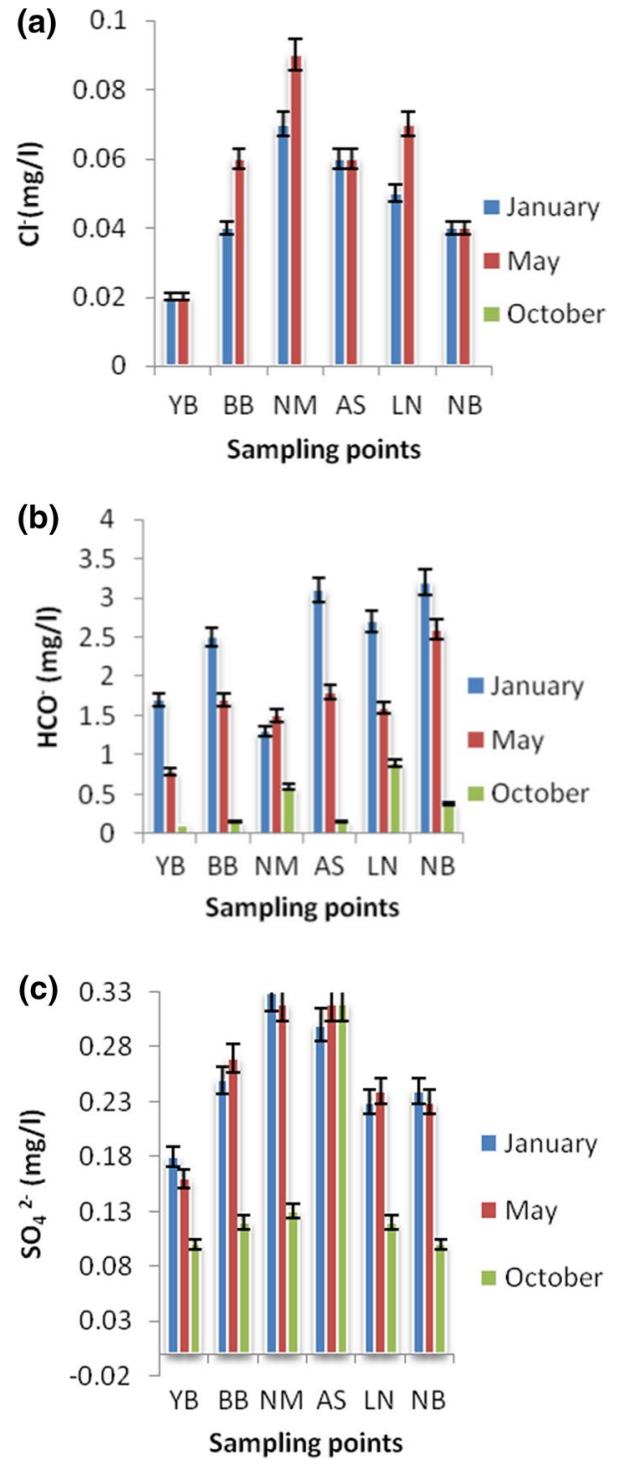

Fig. 4 Seasonal variations in major anions of the Mezam River water

others in the magnesium domain; meanwhile, for the anions, most of the samples plot in the sulphate and some in the $\mathrm{Cl}+\mathrm{NO}_{3}{ }^{-}$fields. In the rainy season, a Ca-Mg- $\mathrm{SO}_{4}{ }^{2-}$ water type is observed since some samples plot in the $\mathrm{Ca}$ and $\mathrm{Mg}$ fields for the cations and almost all samples plot in the $\mathrm{SO}_{4}{ }^{2-}$ fields.

\section{Variation of indicator bacteria in the Mezam River water}

The E. coli occurs in all the sampling points, with mean concentrations ranging from $333.33 \mathrm{CFU} / 100 \mathrm{ml}$ in May to $433.33 \mathrm{CFU} / 100 \mathrm{ml}$ during the January sampling period (Table 4). Seasonal variations are not conspicuous (Fig. 7a). The lowest concentrations (100 CFU/100 ml) are observed at YB and AS in May, while the highest (500 CFU/100 ml) occur at BB, NM and AS. The mean concentration of Streptococcus ranges from $208.33 \mathrm{CFU} / 100 \mathrm{ml}$ in October to $275.50 \mathrm{CFU} / 100 \mathrm{ml}$ in May. The highest concentrations $(500 \mathrm{CFU} / 100 \mathrm{ml})$ appear at NM and NB in January, and the least $(100 \mathrm{CFU} / 100 \mathrm{ml})$ is recorded at $\mathrm{YB}, \mathrm{BB}$, AS, LN and NB (Fig. 8b). Salmonella is detected once at YB (3 CFU/100 ml) in October and twice at BB, LN and $\mathrm{NB}$, whereas it is present at the NM and AS throughout the sampling periods (Fig. 8c). The mean concentration of Salmonella ranges from $20.00 \mathrm{CFU} / 100 \mathrm{ml}$ in January to $151.67 \mathrm{CFU} / 100 \mathrm{ml}$ in May. Proteus species is not detected at the AS and BB sampling points. The mean value ranges from $50 \mathrm{CFU} / 100 \mathrm{ml}$ in October to $196.63 \mathrm{CFU} / 100 \mathrm{ml}$ in January, and there is no observable trend in seasonal variation (Fig. 8d). The lowest concentration $(0.00 \mathrm{CFU} / 100 \mathrm{ml})$ of Proteus is measured at $\mathrm{AS}$ and $\mathrm{BB}$ and the highest (500 CFU/100 ml) at NM.

\section{Discussion}

The Mezam River water in Bamenda is not used directly as a drinking water source, but is rather widely used to irrigate crops grown in the River's floodplain during periods of drought. If the river water used is polluted, it may have a considerable impact on soil properties and plants grown because the contaminants may be absorbed by the crops and would have negative consequences on the population when consumed.

\section{Physico-chemical peculiarities and sources of ions in surface water in Bamenda Town}

The spatial variation of physical characteristics is not very distinct, but variation is perceptible between seasons at some sampling points. The mean temperature of the Mezam River water, varying from $18.3{ }^{\circ} \mathrm{C}$ to $23.4{ }^{\circ} \mathrm{C}$, is a reflection of the average ambient temperature. Temperature is a crucial parameter that controls the distribution, growth, survival and reproduction of organisms in an ecosystem (Vincy et al. 2012). Higher-temperature values within the range of 24.6 to $31{ }^{\circ} \mathrm{C}$ have been observed in the Foma River in Nigeria by Agbabiaka and Oyeyiola (2012). All the water samples show $\mathrm{pH}$ values below neutrality, ranging from 5.12 at Nkimefueh to 6.84 at the Naaka River. This $\mathrm{pH}$ range is compatible with aquatic life, particularly green plants that may serve to aerate and purify the water (Tita et al. 2007). Lower $\mathrm{pH}$ values of 4.7 to 4.9 have been observed by Boeglin et al. (2003) in the Nsimi catchment ( South Cameroon), while Akoanung et al. (2019) have recorded mean $\mathrm{pH}$ values of 5.71 from groundwater samples in Bamenda and Mufur et al. (2021) documented weakly acidic to neutral $\mathrm{pH}$ values of 5.3 to 7.1 in Melong. The EC values vary from $6.09 \mu \mathrm{S} / \mathrm{cm}$ at

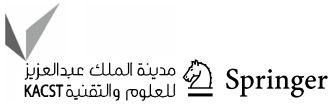


Fig. 5 Seasonal variations of nutrients in the Mezam River water

Fig. 6 Piper diagram showing variation in ion composition of the Mezam River water (a)

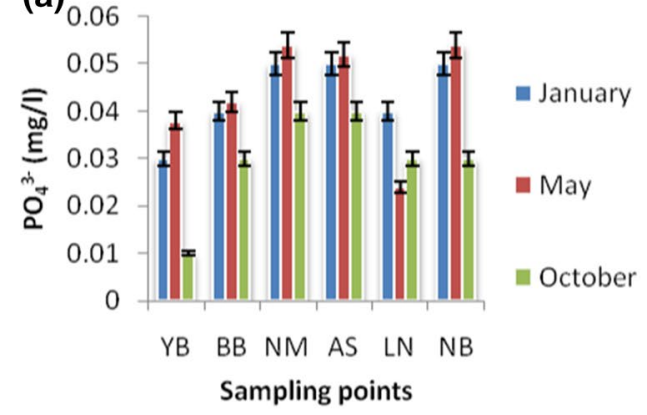

(b)

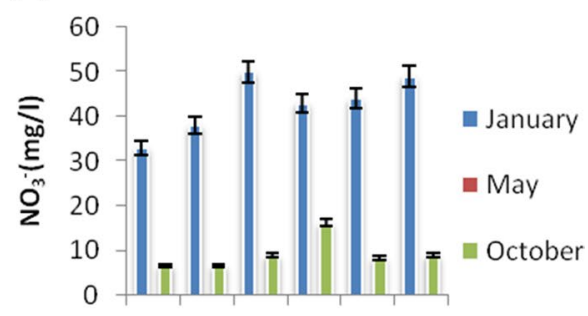

YB BB NM AS LN NB Sampling points
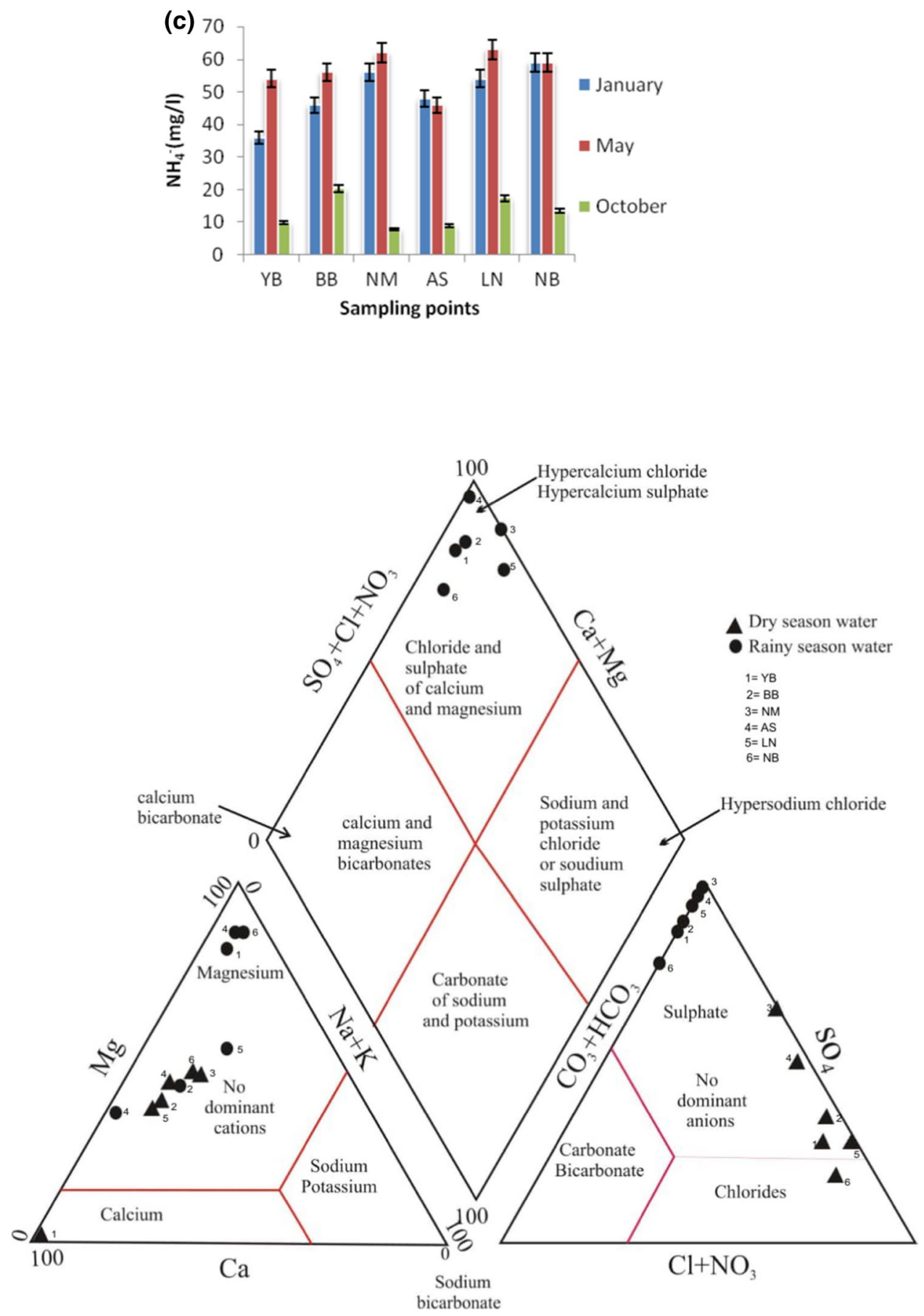
Table 4 Summary statistics of the Mezam water bacteria count for the studied period $(\mathrm{n}=18)$

\begin{tabular}{llllrl}
\hline Variable & Minimum & Maximum & Mean & \multicolumn{1}{l}{ SD } & CV $(\%)$ \\
\hline January $(n=6)$ & & & & & \\
E. coli & 300 & 500 & 433.33 & 103.28 & 23.80 \\
Streptococcus & 100 & 500 & 233.33 & 56.23 & 24.09 \\
Salmonella & 0 & 50 & 20.00 & 10.00 & 50.00 \\
Proteus & 0 & 500 & 196.63 & 52.43 & 26.66 \\
May $(n=6)$ & & & & & \\
E. coli & 100 & 500 & 333.33 & 96.63 & 28.99 \\
Streptococcus & 200 & 300 & 275.00 & 41.83 & 15.21 \\
Salmonella & 0 & 500 & 151.67 & 83.34 & 54.95 \\
Proteus & 0 & 100 & 53.33 & 16.76 & 31.42 \\
October $(n=6)$ & & & & & \\
E. coli & 160 & 500 & 393.33 & 165.73 & 42.13 \\
Streptococcus & 100 & 300 & 208.33 & 102.06 & 48.98 \\
Salmonella & 10 & 200 & 51.67 & 24.40 & 47.20 \\
Proteus & 0 & 150 & 50 & 18.32 & 36.64 \\
January+May & + October $(n=18)$ & & & \\
E. coli & 100 & 500 & 386.66 & 156.13 & 40.37 \\
Streptococcus & 100 & 500 & 238.88 & 130.11 & 54.46 \\
Salmonella & 0 & 500 & 123.99 & 71.44 & 57.61 \\
Proteus & 0 & 500 & 121.51 & 78.89 & 64.92 \\
\hline SD. & 0 & & & &
\end{tabular}

SD: standard deviation; $\mathrm{CV}$ : coefficient of variation

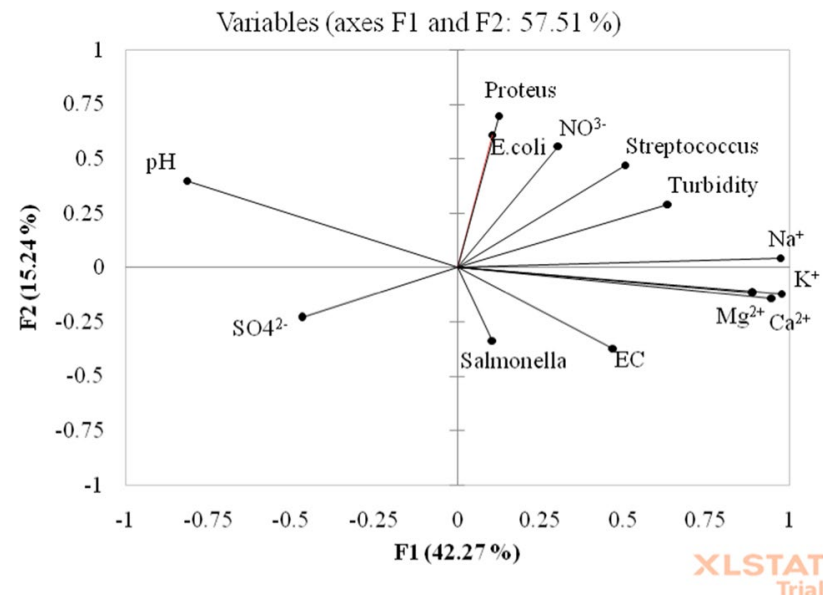

Fig. 7 Graphical representation of the first two principal components of the Mezam water characteristics, extraction method: principal component analysis $(n=18)$

Yambot to $28.5 \mu \mathrm{S} / \mathrm{cm}$ at the Ayaba Segment. In fact, EC for the downstream sampling points at Nkimefueh, Ayaba and Lower Ngomgham always portrays excess values of $50 \mu \mathrm{S} /$ $\mathrm{cm}$, which could be an indication of anthropogenic sources of ions in water. A mean EC value of $421.54 \mu \mathrm{S} / \mathrm{cm}$ has been reported by Engome et al. (2013) in the Rio del Rey Basin (South West Cameroon).
Dissolved oxygen is generally low $(<10 \mathrm{mg} / \mathrm{l})$ and the sampling points in the urban areas (BB and AS) most often maintain a substandard level $(<5 \mathrm{mg} / \mathrm{l})$. The low values of DO are in agreement with results of Togue et al. (2017) in Nkam River. The amount of dissolved oxygen in water is a good indicator of water quality and the kind of aquatic life that can be supported. Organic wastes such as food processing waste, runoff from feedlots and piggery, stimulate oxygen consumption by decomposers (Bishop and Prosser 2002). When these microorganisms breakdown the organic materials, they use up oxygen (hence the name oxygendemanding wastes) resulting to a decrease in oxygen content in water. The AS and BB sampling points (Figs. 9, 10) are characterised by huge quantities of refuse from commercial as well as residential areas of the town. Low DO levels have been observed by Fatema et al. (2014) in the Merbok estuary.

The cation concentration of the water during the study period followed the following trend: $\mathrm{Ca}^{2+}>\mathrm{Mg}^{2+}>\mathrm{Na}^{+}>\mathrm{K}^{+}$. From Table 3, it is noticed that the chemical constituents controlling surface water chemistry in the study area are the major cations which might stem from the weathering of silicate minerals in the surrounding rocks. The anion concentration is such that $\mathrm{HCO}_{3}{ }^{-}>\mathrm{SO}_{4}{ }^{2-}>\mathrm{NO}_{3}{ }^{-}>\mathrm{Cl}^{-}$. The high $\mathrm{HCO}_{3}{ }^{-}$ion concentrations might result from dissolved $\mathrm{CO}_{2}$ in precipitation according to Tanyileke et al. (1996); this is a characteristic of natural waters along the CVL. However, the marked increase in their respective concentrations downstream lends credence to additional anthropogenic inputs. This is particularly so with heavy metal levels during the May sampling period at BB, NM, AS and NB river segments. Similarly, nitrate concentrations attained the FAO (1994) limits of $50 \mathrm{mg} / \mathrm{l}$ at NM in May. This is justifiable in Fig. 9 where the NM sampling point is highly variable from the other sampling points. Here, the water samples are less variable in terms of physico-chemical characteristics with a total variance weight of $41.70 \%$ relative to the higher variability of samples in terms of bacteria count with a variance expression of $69.22 \%$.

\section{Sources of ionic constituents in the studied surface water}

The correlation matrix is useful in establishing relationships among variables. The Pearson correlation matrix (Table 5) showed that strong positive correlation exists between $\mathrm{Ca}^{2+}$ and $\mathrm{Mg}^{2+}(0.91), \mathrm{K}^{+}(0.83)$ and $\mathrm{Na}^{+}(0.88) . \mathrm{Mg}^{2+}$ on the other hand is strongly positively correlated with $\mathrm{K}^{+}(0.96)$ and $\mathrm{Na}^{+}(0.95)$, while $\mathrm{K}^{+}$is strongly positively correlated with $\mathrm{Na}^{+}(0.91)$. This may result from natural hydrogeochemical processes of weathering of the surrounding rocks to liberate the cations into the water. This corroborates with 
Fig. 8 Seasonal variations in a E. coli; b Streptococcus

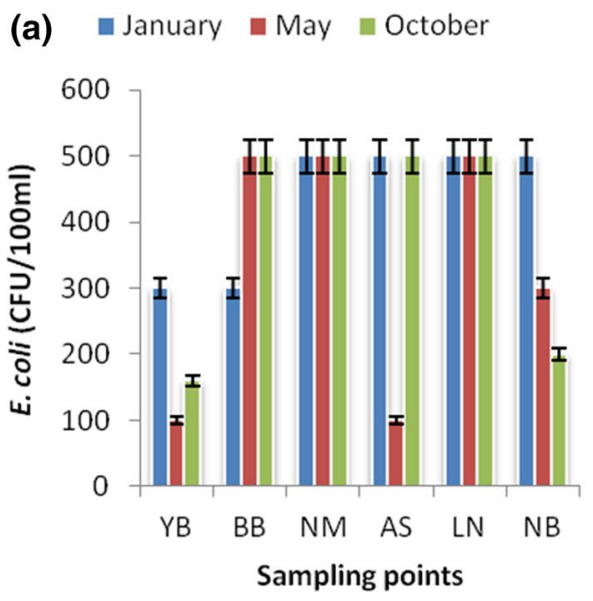

(c) January $\square$ May @ October

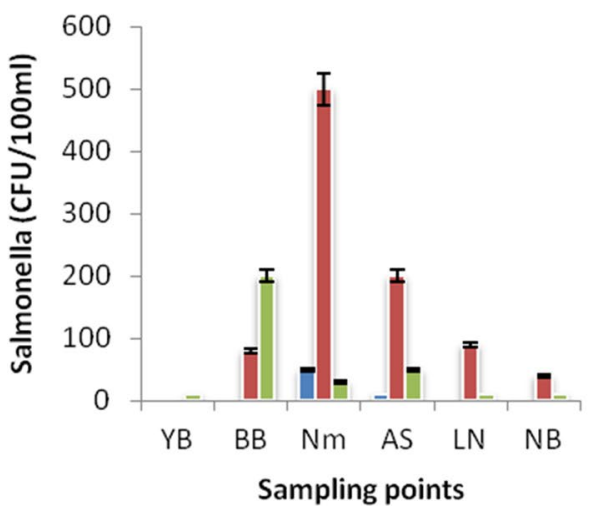

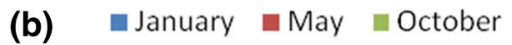

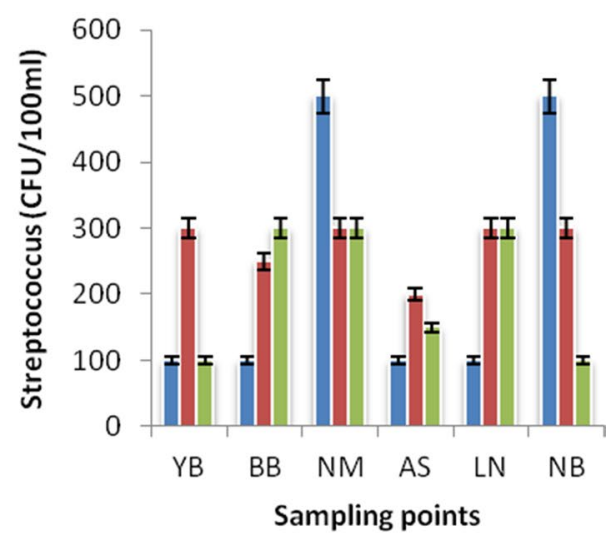

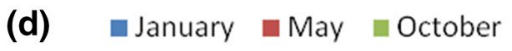

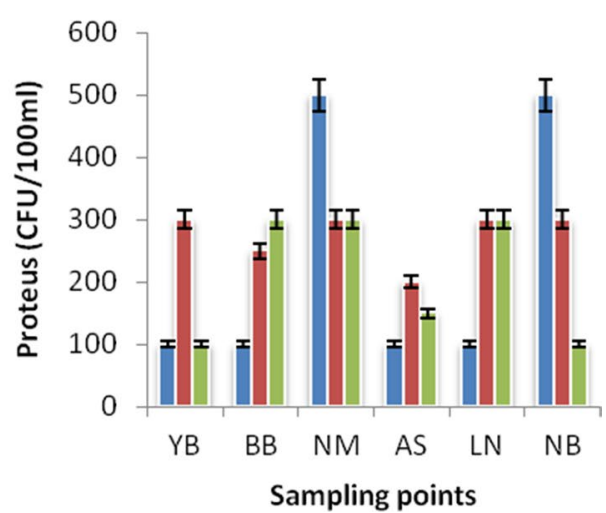

the study of Magha et al. (2021) in which Gibbs plot indicated that groundwater chemistry in Northern Bamenda is controlled principally by rock weathering. Moreover, the principal component analysis (PCA) was used to elucidate the provenance of major ions in the studied water. Among the dominant constituents, the distribution of the PCA variables in the factorial spread F1-F2 revealed two important groups (Fig. 7). The first group in the first quadrant is made up of turbidity, $\mathrm{Na}^{+}, \mathrm{NO}_{3}{ }^{-}$, E. coli, Streptococcus and Proteus, while the second quadrant is made up of $\mathrm{EC}, \mathrm{Mg}^{2+}$, $\mathrm{Ca}^{2+}, \mathrm{K}^{+}$and Salmonella. The ionic components that determine water mineralisation may result from natural processes of mineral decomposition, atmospheric deposition or breakdown of organic matter or as well from human sources as is the case for the indicator bacteria (Rakotondrabe et al. 2018).

\section{Bacteriological levels and anomalies of surface water in Bamenda Town}

The occurrence of faecal indicator bacteria in all the sampling points reflects the different human activities carried out in the neighbourhood as well as the population density. The lowest concentration of indicator bacteria of pollution is gotten at the YB sampling point situated in an undeveloped area below the Bamenda Highlands where contributions from human influence are at a minimum. The occurrence of high bacteria counts indicates that the source is not necessarily human but rather other warm-blooded animals (Park 2001; Abednego et al. 2013). The highest concentrations of faecal indicator bacteria were measured at BB and NM. The BB sampling point is situated downstream at a densely populated area where a good number of households do not have adequate sanitary facilities, and in most cases, effluents are channelled directly into the waterway. In addition, there are small-scale piggeries and poultries in the back yards of many homes whose wastes constantly flow into the river channel. This result corroborates with the results of Kuitcha et al. (2010) in the Mfoundi watershed in Yaoundé, Cameroon. In particular, the NM sampling point is located downstream to the Bamenda slaughterhouse where the waste is conveyed into the river channel, possibly raising the concentrations of faecal bacteria.

The bacteria concentrations also show seasonal variations with comparatively higher levels in the dry season and onset of rains and lower levels in the rainy season. In the dry 


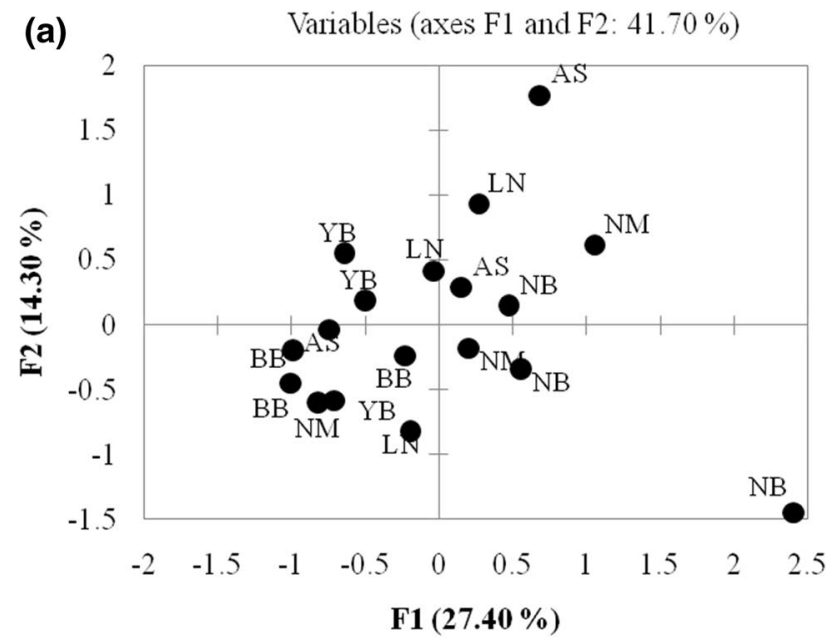

(b) Variables (axes F1 and F2: 69.22\%)

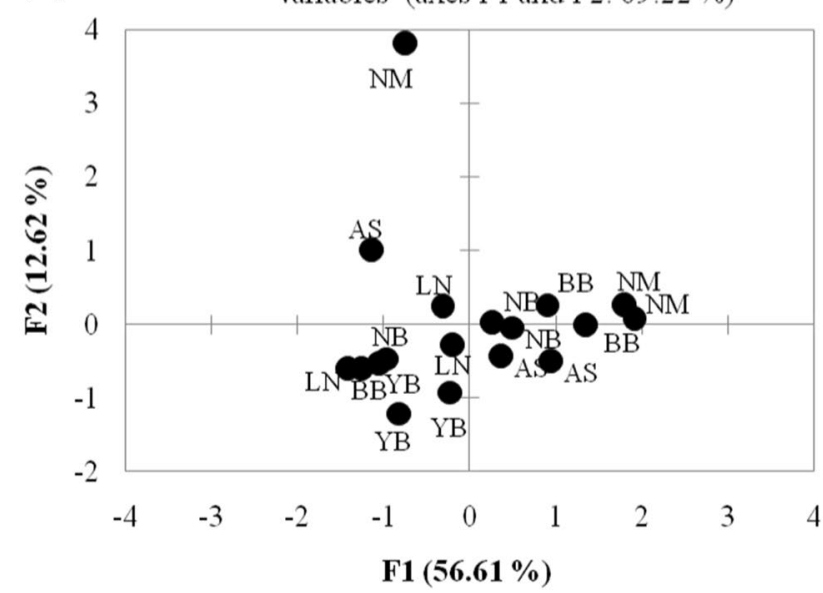

Fig. 9 Factor separation showing variability of water sampling points in terms of bacterial count (a) and physico-chemical analysis (b) of the Mezam season, the volume of water in the river is greatly reduced rendering it more accessible to both humans and animals as already observed by Tita et al. (2013).

\section{Implications for surface water management}

Water pollution is an acute environmental problem that results from rapid population growth and can have many adverse effects on human health, aquatic environment, agricultural productivity, natural ecosystems and the cost of treatment of water for drinking. The pollution of the Mezam River water in Bamenda has greatly affected its usage, including the recreational value of the resource. A great multitude of diseases that affect humans is transmitted through polluted water, either directly through drinking contaminated water or indirectly through consumption of food stuffs, especially vegetables that are irrigated with polluted water. The health impact of water pollution in the Bamenda area can be aggravated as many residents do not understand the implications that could arise from using urban water bodies and continue to use the water to water vegetables (huckleberry) that are widely consumed in Bamenda and other towns of Cameroon.

\section{Conclusion}

This study aimed to investigate the physico-chemical and bacteriological characteristics of surface water in Bamenda Town (North West Cameroon). The main results reveal that the surface water in Bamenda Town is slightly acidic with $\mathrm{pH}$ values varying from 5.12 to 6.84 . The implication of the acidic water when it comes in contact with geologic materials of the surroundings is that it may dissolve some minerals and incorporate them into
Fig. 10 Refuse dumped at some sampling points in the Mezam River water
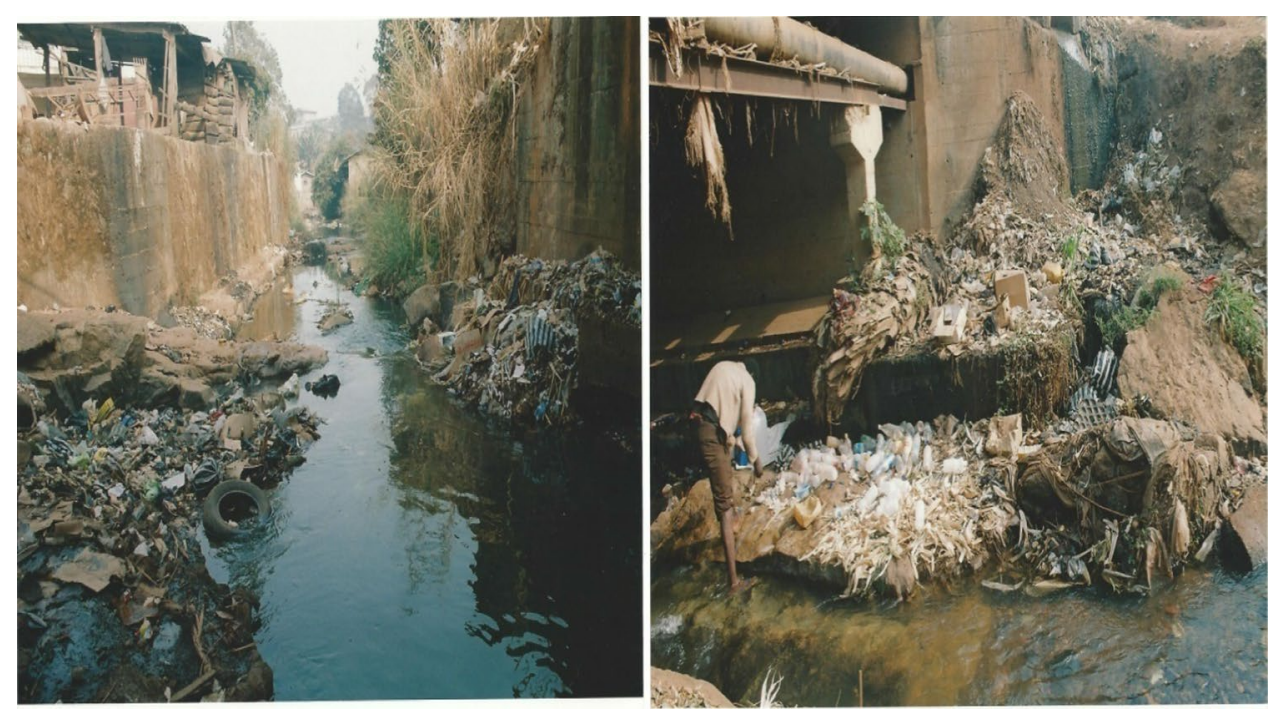

$\checkmark$ 
Table 5 Correlation among selected Mezam water characteristics for the studied period $(n=18)$

\begin{tabular}{|c|c|c|c|c|c|c|c|c|c|}
\hline Variables & $\mathrm{pH}$ & $\mathrm{EC}$ & Turbidity & $\mathrm{Ca}^{2+}$ & $\mathrm{Mg}^{2+}$ & $\mathrm{K}^{+}$ & $\mathrm{Na}^{+}$ & $\mathrm{SO}_{4}^{2-}$ & $\mathrm{NO}^{3-}$ \\
\hline $\mathrm{pH}$ & 1.00 & & & & & & & & \\
\hline $\mathrm{EC}$ & -0.39 & 1.00 & & & & & & & \\
\hline Turbidity & -0.43 & 0.16 & 1.00 & & & & & & \\
\hline $\mathrm{Ca}^{2+}$ & $-0.67 * *$ & $0.55 *$ & 0.33 & 1.00 & & & & & \\
\hline $\mathrm{Mg}^{2+}$ & $-0.85 * *$ & $0.46 *$ & $0.55 *$ & $0.91 * *$ & 1.00 & & & & \\
\hline $\mathrm{K}+$ & $-0.86 * *$ & 0.44 & $0.58 *$ & $0.83 * *$ & $0.96 * *$ & 1.00 & & & \\
\hline $\mathrm{Na}+$ & $-0.74 * *$ & 0.41 & $0.57 *$ & $\mathbf{0 . 8 8} * *$ & $0.95 * *$ & $0.91 * *$ & 1.00 & & \\
\hline $\mathrm{SO}^{2-}$ & 0.21 & 0.29 & -0.15 & $-0.49 *$ & -0.44 & -0.37 & $-0.55 *$ & 1.00 & \\
\hline $\mathrm{NO}^{3-}$ & -0.04 & 0.12 & 0.10 & 0.24 & 0.25 & 0.28 & 0.35 & -0.19 & 1.00 \\
\hline E.coli & 0.29 & 0.12 & 0.23 & 0.13 & -0.03 & -0.07 & 0.09 & -0.15 & 0.32 \\
\hline Streptococcus & -0.29 & 0.03 & $0.67 * *$ & 0.23 & 0.38 & 0.35 & $0.48 *$ & -0.21 & 0.07 \\
\hline Salmonella & -0.18 & 0.29 & -0.02 & 0.13 & 0.03 & -0.05 & 0.08 & -0.15 & -0.41 \\
\hline Proteus & 0.10 & -0.11 & 0.18 & 0.08 & 0.06 & -0.01 & 0.14 & -0.08 & 0.36 \\
\hline
\end{tabular}

*Correlation is significant at the 0.05 level; **correlation is significant at the 0.01 level

The very high factor loadings of some variables in bold imply that the chemistry of water is controlled mainly by those variables the water, thereby enriching the chemical content of the water. The cation concentration of the studied water is such that $\mathrm{Ca}^{2+}>\mathrm{Mg}^{2+}>\mathrm{Na}^{+}>\mathrm{K}^{+}$. The high $\mathrm{Ca}^{2+}$ content might be derived from the weathering of feldspar and hornblende present in the country rocks. Heavy metals were detected in the water in very low concentrations at some sampling points and were completely absent in most samples. The Mezam River water is polluted with different faecal bacteria, with high levels attaining $500 \mathrm{CFU} / 100 \mathrm{ml}$ mainly in the city centre. Some physical and bacteriological parameters show great variations from the reference point and various sampling points, increasing from the reference point through sampling points in the urban centre. Remarkable seasonal variations are perceived in the physical, chemical and bacteriological parameters in the studied surface water samples in Bamenda Town. The major cations and anions in the studied water in Bamenda Town result mainly from the alteration of various country rocks within the water shed of the Mezam River system. The high pollutant loads degrade the quality of surface water in Bamenda Town. The population is therefore urged to adopt a responsible behaviour towards waste disposal and refrain from disposing wastes into the river channel in order to safeguard the aquatic environment and also protect the health of the population.

Acknowledgements We would like to thank the staff of the Research Unit of Soil and Environmental Chemistry, University of Dschang, Cameroon, for assisting in conducting the hydrochemical analyses and those of the Laboratory of Animal Physiology and Microbiology for helping in the microbiological characteristics. We also thank the two reviewers for their valuable comments which ameliorated the quality of the manuscript.
Funding This study did not receive any funding from any organisation.

\section{Declaration}

Conflict of interest The authors declare that they have no conflict of interest.

Open Access This article is licensed under a Creative Commons Attribution 4.0 International License, which permits use, sharing, adaptation, distribution and reproduction in any medium or format, as long as you give appropriate credit to the original author(s) and the source, provide a link to the Creative Commons licence, and indicate if changes were made. The images or other third party material in this article are included in the article's Creative Commons licence, unless indicated otherwise in a credit line to the material. If material is not included in the article's Creative Commons licence and your intended use is not permitted by statutory regulation or exceeds the permitted use, you will need to obtain permission directly from the copyright holder. To view a copy of this licence, visit http://creativecommons.org/licenses/by/4.0/.

\section{References}

Abednego M, Mbaruk A, John M, John M (2013) Water borne bacterial pathogens in surface waters of Nairobi River and health implications on communities downstream Athi River. International Journal of Life Science and Pharma Research, Volume 3

Acho C (1998) Human interference and environmental instability addressing the environmental consequences of rapid urban growth in Bamenda, Cameroon Environment and Urbanization Univ. Buea 10:161-174

Agbabiaka TO, Oyeyiola GP (2012) Microbial and physicochemical assessment of Foma River, Itanmo, Ilorin, Nigeria: an important source of domestic water in ilorin metropolis. Int J Plant Anim Environ Sci 2(1):2231-4490

Ako AA, Eneke GTE, Nkeng GE (2010) Water resources management and integrated water resources management (IWRM) in cameroon. Water Resour Manage 24:871-888 
Akoanung A, Endene E, Enoh JF, Akoachere RA (2019) Assessment of groundwater quality in Bamenda-Cameroon for suitable applications. Springer Nature 1:1389. https://doi.org/10.1007/ s42452-019-1351-1

Alabi AA,·Popoola OI,-Olurin OT, -Ogungbe AS, Ogunkoya· OA, Okediji SO, (2020) Assessment of groundwater potential and quality using geophysical and physicochemical methods in the basement terrain of Southwestern. Nigeria Environ Earth Sci 79:364. https://doi.org/10.1007/s12665-020-09107-y

Atteia O (2005) Chemistry and pollution of underground waters. In: Engome RW, Ayonghe SN, Fantong WY, Mengnjo JW, Takeshi O (2013) Hydrogeochemical and anthropogenic influence on the quality of water sources in the Rio del Rey Basin, South Western, Cameroon, Gulf of Guinea. Afr. J. Environ. Sci. Technol. 7(12):1054-1070

Bishop V, Prosser R (2002) water resources: processes and management, 2nd edn. Collins, Birmingham

Boeglin JL, Ndam JR, Braun JJ (2003) Composition of the different reservoir waters in a tropical humid area: example of the Nsimi catchment (Southern Cameroon). J Afr Earth Sc 37:103-110

Chapman D (1998) Water quality assessment, a guide to the use of biota, sediments and water in environmental monitoring, 2nd edn. $\mathrm{E}$ and $\mathrm{F}$ N SPON, London

Cheesbrough M (1991) Medical laboratory manual for tropical countries, low priced edition, Daddington, Cambridgshire

Engome RW, Ayonghe SN, Fantong WY, Wirmvem MJ, Takeshi O (2013) Hydrogeochemical and anthropogenic influence on the quality of water sources in the Rio del Rey Basin, South Western, Cameroon, Gulf of Guinea. Afr J Environ Sci Technol 7(12):1053-1069. https://doi.org/10.5897/AJEST2013.1578

FAO (1994) Irrigation and drainage paper 29. FAO, Rome

Fatema K, Wan WO, Isa MM (2014) Spatial variation of water quality parameters in a mangrove estuary. Int J Environ Sci Technol. https://doi.org/10.1007/s13762-014-0603-2

Kamgang P, Njonfang E, Nono A, Gountie DM, Tchoua F (2010) Petrogenesis of a silicic 95 magma system: Geochemical evidence from Bamenda Mountains, NW Cameroon 596 Volcanic Line. J Afr Earth Sc 58:285-304

Kometa SS (2013) Wet land exploitation along the bafoussambamenda road axis of the western highlands of cameroon. J Hum Ecol 41:25-32

Kuitcha D, Ndjama J, Tita AM, Lienou G, Kamgang KBV, Ateba BH, Ekodeck GE (2010) Bacterial contamination of water points of the upper Mfoundi watershed, Yaounde. Cameroon Afr J Microbiol Res 4(7):568-574

MacFaddin JF (2000) Biochemical tests for identification of medical bacteria, 3rd edn. Lippincott Williams \& Wilkins, Philadelphia

Mary Banke O, · Udeme JJI, · Jonathan Y, · Peter Olabisi A, DDamola SA, J Julius NI, (2020) Purification efficacy of different parts of Mangifera indica on water samples from contaminated drinking water sources in chanchaga local government area of Niger State. Nigeria Appl Water Sci 10:102. https://doi.org/10.1007/ s13201-020-01183-6

Molua EL, Lambi CM (2006) Climate, hydrology and water resources in Cameroon. CEEPA, Pretoria

Mufur AM, Tita MA, Tamfuh PA, Agendia MA, Ngambu AA, Kabeyene KV (2021) Groundwater resources for domestic and irrigation purposes in Melong (Littoral Region, Cameroon): Hydrogeochemical constraints. Afr J Environ Sci Technol 15(7):270-281. https://doi.org/10.5897/AJEST2021.3027

Ndenecho E, Eze BE (2004) Geomorphic and anthropogenic factors influencing landslides in the Bamenda highlands. N.W Province. Cameroon J Appl Soc Sci 1:15-26

Nono GDK, Wotchoko P, Magha A, Ganno S, Ndam N, Ngambu AA, Nzenti JP, Kamgang VK (2018) Contrasting Ba-Sr granitoids from bamenda area, NW cameroon: sources characteristics and implications for the evolution of the pan African fold belt. J Geosci Geom 6(2):65-76

Nyenje PM (2014) Fate and transport of nutrients in groundwater and surface water in an urban slum catchment, Kampala, Uganda $\mathrm{PhD}$ Thesis, The Netherlands

Nzenti JP, Abaga B, Suh CE, Nzolang C (2010) Petrogenesis of peraluminous magmas from the Akum-Bamenda Massif, Pan-African Fold Belt, Cameroon, Int Geol Rev. 1-29

Park C (2001) The environment: principles and applications, 2nd edn. Routledge, New York

Piper AM (1953) A graphic procedure in the geochemical interpretation of water analysis. US Geological Survey, Washington, DC

Rakotondrabe F, Ngoupayou JRN, Mfonka Z, Rasolomanana EH, NAbolo AJ, Ako AA, (2018) Water quality assessment in the BétaréOya gold mining area (East-Cameroon): Multivariate Statistical Analysis approach. Sci Total Environ 610-611:831-844

Shrikant K, Shridhar K, Prajkta J (2020) Water quality analysis of Urun-Islampur City, Maharashtra. India Appl Water Sci 10:95

Simona MF, Dumitru FF (2012) Water infrastructure and socio-economic development issues. Res Gate. https://doi.org/10.13140/ RG.2.1.3217.2642

Tanyileke GZ, Kusakabe M, Evans WC (1996) Chemical and isotopic characteristics of fluids along the CVL, Cameroon. J Afr Earth Sci 22:433-441

Tita MA, Tsala GN, Kamgang KVB, Parisot JC, Ndjama J (2007) Macrophytes and water quantity of the Nkoup River system. J Cameroon Acad Sci 7:59-69

Tita MA, Kamgang KVB, Tsala GN (2009) Microbial pollution of surface water and its health impact in the Nkoup river basin in foumbot. West Cameroon Revue CAMES- Serie a 8:56-61

Tita MA, Magha A, Kamgang KVB (2013) Microbial pollution of the Mezam River system and its health impacts in Bamenda (North West Cameroon), African. J Microbiol Res 7:4940-4948

Togue FK, Kuate GLO, Oben LM (2017) Physico-Chemical characterization of the surface water of Nkam river using the principal component analysis. J Mater Environ Sci 8:1910-1920

UNEP GEMS/Water Programme (2006) Water Quality for Ecosystem and Human Health, http://www.gemswater.org.

UNESCO (2003) Water for people, water for life. United Nations Educational, Scientific and Cultural Organization. Paris: UN World Water Development Report (WWDR). UNESCO and Berghahn, New York

Vincy MV, Rajan B, Pradeep Kumar AP (2012) Water quality assessment of a tropical wetland ecosystem with special reference to Backwater Tourism, Kerala, South India. Int Res J Environ Sci 1(5):62-68

UN Water (2011) Water quality challenges and impacts

UN Water (2018) Sustainable development goal 6. Synthesis report on water and sanitation, Geneva, Switzerland

Wirmvem MJ, Takeshi O, Fantong WY, Ayonghe SN, Suila JY, Asobo NE, Tanyileke G, Hell JV (2013) Hydrochemistry of shallow groundwater and surface water in the Ndop plain, North West Cameroon. Afr J Environ Protect Technol 7(6):518-530

World Bank (2012) Rural water supply design manual, vol 1. Water Partnership Program; Manila, Philippine

Ylldiz D (2017) The Importance of Water in Development 1. World Water Diplomacy \& Science News, Hydropolitics Academy, Ankara

Publisher's Note Springer Nature remains neutral with regard to jurisdictional claims in published maps and institutional affiliations. 